\title{
«Вынужденная миграция» граждан государств-противников на начальном этапе Первой мировой войны и ее отражение на страницах российской периодической печати
}

\author{
Николаева Е.B. \\ Брянский государственный университет им. академика И.Г. Петровского, \\ 241036, г. Брянск, ул. Бежицкая, д. 14 \\ E-mail: omc-c@yandex.ru
}

\begin{abstract}
Аннотация. Так называемое «немецкое засилье» в России в годы Первой мировой войны вызвало широкий общественный резонанс и послужило основанием для правовых ограничений всех подданных воюющих с Россией государств. В статье рассматриваются причины этого явления, вызванного не только вполне естественным отрицательным отношением к врагу, противостоявшему российской армии, но и попытками создать своеобразное единство в сфере этнических отношений. Результатом явилось появление наряду с беженцами «вынужденных мигрантов», ряды которых состояли в том числе и из российских подданных немецкого и австрийского происхождения, многие десятилетия проживавших на территории России. Российская власть в какой-то мере оценивала возможные экономические последствия подобных мер, принявших массовый характер, но, находясь под постоянным давлением со стороны общества и армейского командования, вынуждена была предпринять шаги по введению ограничительных законов в отношении «внутренних врагов».
\end{abstract}

Ключевые слова: Первая мировая война, беженцы, «вынужденная миграция», «немецкое засилье», мобилизация внутренних ресурсов.

Для цитирования: Николаева Е.В. 2021. «Вынужденная миграция» граждан государствпротивников на начальном этапе Первой мировой войны и ее отражение на страницах российской периодической печати. Via in tempore. История. Политология, 48 (2): 435-444. DOI: 10.52575/2687-0967-2021-48-2-435-444.

\section{«Forced Migration» of Citizens of Opposing States at the Initial Stage of the First World War and its Reflection on the Pages of the Russian Periodicals}

\author{
ElenaV. Nikolaeva \\ Bryansk State University named after academician I.G. Petrovsky, \\ 14 Bezhitskaya St., Bryansk, 241036, Russia \\ E-mail: omc-c@yandex.ru
}

\begin{abstract}
The so-called «German strangehold» in Russia during the First World War sparked a massive public outcry and served as the basis for legal restrictions on all subjects of the states waging war with Russia. The article examines the reasons for this phenomenon which was caused not only by a completely natural negative attitude towards the enemy opposing the Russian army, but also by attempts to create a kind of unity in the sphere of ethnic relations. The result was the emergence, along with the refugees, of «forced migrants», whose ranks consisted, among other things, of Russian citizens of German and Austrian origin, who had been living in Russia for many decades. The Russian authorities to some extent assessed the possible economic consequences of such measures, which took place on a massive scale, but, being under constant pressure from society and the army command, they had to take steps to introduce restrictive laws against «internal enemies».
\end{abstract}


Key words: World War I, refugees, «forced migration», «German stranglehold», mobilization of internal resources.

For citation: Nikolaeva E.V. 2021. «Forced Migration» of Citizens of Opposing States at the Initial Stage of the First World War and its Reflection on the Pages of the Russian Periodicals. Via in tempore. History and political science, 48 (2): 435-444 (in Russian). DOI: 10.52575/2687-0967-2021-48-2-435-444.

\section{Введение}

Начало Первой мировой войны было встречено с восторгом во всех странах, вступивших в нее. Однако признанный американский специалист по российской военной истории У. Фуллер, характеризуя общественную атмосферу, царившую в государствахучастницах, отмечал, что «...общественный патриотизм и национальный подъем имели свою обратную сторону - рост шовинизма и ксенофобии. Всё связанное с ненавистным врагом демонстративно отвергалось и предавалось публичному поруганию» [Фуллер, 2009, c. 205-206].

Рассмотрение истории вынужденных мигрантов наметилось уже в ходе продолжавшейся войны и продолжилось сразу после ее окончания. Однако в исследованиях советского периода развития исторической науки тема беженства и выселенцев не нашла отражения даже в обобщающих трудах по истории Первой мировой войны. Редким исключением были работы демографического порядка. Только с конца 1990-х гг. на основе привлечения новых документов, хранящихся в архивах, началось активное восстановление детальной картины этой катастрофы, произошедшей в годы Первой мировой войны. Масштабы случившегося требуют новых исследовательских усилий, тем более что концептуализация феномена беженства и в рамках этого явления судьба вынужденных переселенцев не возможна без пристального изучения фактических сторон прошлой трагедии. Рассматриваемая статья должна внести свой вклад в решение этой исследовательской задачи.

\section{Объекты и методы исследования}

В книге американского историка Эрика Лора, посвященной политике притеснения в отношении подданных воевавших против России государств, отмечается, что «общественная мобилизация против широко разбросанных по империи вражеских меньшинств усиливала не общеимперский, а территориальный национализм» [Лор, 2012, с. 202]. Практически за счет выселяемых происходило утверждение новой тенденции в процессе национализации ряда районов страны. Совершенно очевидно, что «шпиономания» и прочие проблемы «засилья», якобы наблюдавшиеся со стороны инородцев, играли исключительно подчиненную роль в условиях решения важных политических задач.

Информационный потенциал архивных источников и материалов периодической печати позволяет осветить заявленную тему статьи, хотя многие из обозначенных проблем еще ждут своего детального рассмотрения. В исследовании были использованы как собственно исторические методы: сравнительно-исторический, ретроспективный, так и специальные, к которым можно отнести метод исследования социальной психологии.

\section{Результаты и их обсуждение}

В Российской империи, где начавшаяся война получила в народе название «германской», «ненавистный враг» для широких кругов общественности был очевиден немецкое население. Причем речь шла об общности, которая на протяжении длительного времени проживала рядом с русскими.

Российская государственная политика империи с середины XVIII в. всячески поощряла иммиграцию из Европы с целью колонизации пограничных территорий. Так, Манифестом 22 июля 1763 г. «О дозволении всем иностранцам, в Россию въезжающим, по- 
селяться в которых губерниях они пожелают и о дарованных им правах» провозглашалось, что «в числе иностранных желающих в Россию на поселение случатся и такие, которые для проезда своего не будут иметь довольного достатка, то оные могут являться у министров и резидентов наших, находящихся при иностранных дворах, от коих, не только на иждивении нашем немедленно в Россию отправлены, но и путевыми деньгами удовлетворены будут» [Манифест, 1763, с. 313].

Согласно переписи населения 1897 г., более двух миллионов человек среди переселенцев на невозделанные земли южных степных районов, Поволжья, Северного Кавказа и других областей с целью контроля над малонаселенными районами и введения в хозяйственный оборот пустующих земель составляли немецкие фермеры-колонисты [Лор, 2012, c. 14]. На первом месте по размерам площадей находилась Таврическая губерния, затем следовали Херсонская, Бессарабская и Волынская. Земельные угодья, принадлежавшие выходцам из Германии, находились также в Лифляндской, Петроградской, Холмской, Варшавской, Люблинской губерниях, в Финляндии. Всего этнических немцев, которые встретили начавшуюся войну на территории Российской империи, насчитывалось около 3 млн человек [Фуллер, 2009, с. 207].

Борьба с так называемым «немецким засильем» в России не только отмечалась масштабными всплеском общественных эмоций, которые трансформировались в ксенофобию и шпиономанию, но и повлекла законодательные изменения, превратившись в конкретные направления внутренней политики страны. Такого рода изменения в российских законах периода Первой мировой войны чаще всего именуется в научных исследованиях как «ликвидационное законодательство», и если в целом правовой аспект проблемы получил освещение в исторической и юридической литературе, то анализ особенностей проведения этого направления государственной политики, а также ее влияние на экономическую ситуацию в стране и усиление социального напряжения в различные периоды войны еще далек от своего завершения и справедливо относится к малоизученным темам [Ерохина, 2014, с. 69].

В рамках статьи не представляется возможным рассмотрение всех перечисленных вопросов. Тем не менее, опираясь в основном на материалы периодической печати, в том числе на те из них, которые не были допущены военными цензорами к изданию (однако сохранились в соответствующих фондах РГИА), предполагается осветить некоторые аспекты проблемы. Прежде всего речь пойдет о роли периодической печати в дискредитации немецкого населения для решения политических и экономических задач, а также о формах подачи с этой целью информации в СМИ.

На страницах печати одно из ключевых мест на первом этапе войны отводилось формированию «образа врага». Такого рода действия предпринимались во всех воюющих странах и были вполне объяснимы с точки зрения необходимости формирования определенных настроений тех, кто находился на фронте. Однако российская печать буквально с первых дней военных действий начала разжигание подозрительности и нетерпимости по отношению к выходцам из Германии, традиционно и успешно помимо земледелия и торговли трудившихся в промышленности, проявлявших себя в науке и на военной службе, формируя образ «внутреннего врага»: «Да, они устроились очень удобно, у них много довольства, прочные хозяйственные постройки, кожаная сбруя на лошадях. Они очень трудоспособны, настойчивы. Они, безусловно, честны, но той тупой, прямолинейной, беспощадной честностью сытого человека, которая убивает...» [Земская мысль, 1915. 18].

Начиная с октября 1914 г. набирала силу идея освобождения России от немецкого влияния. Война представлялась удачным способом разрешения якобы назревавшего на протяжении многих лет этого «государственного вопроса». В действительности речь зачастую шла о корпоративных интересах определенных российских кругов. Так, в ноябре 1914 г. Московское купеческое общество вместе с призывом к борьбе с «германским засильем» в деле производства промышленных товаров опубликовало и разослало опросник 
по торгово-промышленной предприятиям России. Предлагалось ответить на вопросы, которые помогли бы решить эту проблему. Призыв нашёл широкий отклик, и общество получило многочисленные ответы, на основе которых специальной комиссией был подготовлен доклад. Причинами распространения германских товаров в России большинство заполнивших анкету назвали их доброкачественность и дешевизну с одной стороны и прекрасную организацию коммерческой части немецких предприятий - с другой. Плохое распространение российских товаров на государственном рынке связывалось с неудовлетворительным отношением крупных фабрикантов к мелким производителям и перекупщикам, отсутствие кредитования. Также ссылались на русского потребителя, зараженного «ложным вредным убеждением о преимуществе всего иностранного» [Меры борьбы с германским засильем, 1915].

Особенно часто корреспонденты рекомендовали бойкот германских товаров, причём они не скрывали все трудности проведения его в жизнь. Необходимыми условиями успеха такого рода действий считали наличие общей организации русских купцов и промышленников и специальной справочной посреднической организации, которая могла бы устранить беспомощность в деле получения товаров мелких провинциальных торговцев.

Среди мер государственного характера указывалось на необходимость льготных торговых договоров, устройство подъездных путей к северным портам и понижение тарифов, на законодательную борьбу с германским засильем, а также на прекращение доступа после войны германским торговым агентам на российский рынок [Там же]. Все предложенные меры свидетельствовали о неминуемом глубоком кризисе, угроза которого нависала над отечественными торгово-промышленными предприятиями в случае ухода с российского рынка выходцев из Германии и Австро-Венгрии. Выход заключался в масштабной экономической перестройке, которую необходимо было осуществлять в условиях набиравшей силу войны.

Кампания по выселению немцев-колонистов из приграничных районов, которая первоначально осуществлялась по инициативе военных властей и объяснялась опять-таки вопросами безопасности, достаточно быстро обнаружила экономическую подоплеку, а именно - желание безвозмездной экспроприации их земель. И в этом случае авторы публикаций в периодической печати пытались переложить ответственность на самих немцев.

Газета «Земская мысль» в январе 1915 г. утверждала: «Призвали к нам немцев для бескровного завоевания края (имелись ввиду южно-русские степи), предполагалось одно, а вышло совсем другое» [Немецкие колонии, 1915. Земская мысль, 17]. Автор статьи о немцах-колонистах заявлял, что задача внесения в новые земли начал европейской культуры не была решена. Выходцам из Германии было выдано от 60 до 80 десятин земли, каждому на постройку усадьбы - от 400 до 600 рублей, 35 рублей - на корову и 100 рублей - на приобретение рабочего скота. Они были освобождены на первые десять лет от всяких податей и повинностей, а после этого срока за десятину земли требовалось платить лишь 15 копеек в год, существовали и другие льготы. «Нет ничего удивительного в том, отмечал автор статьи, - что немцы-колонисты стали все, за ничтожными исключениями, невероятно богатеть» [Немецкие колонии, 1915. Земская мысль, 17]. Отсюда напрашивался вывод: «Самое существование немецкой земли на русской земле неправильно и в таком виде, как сейчас, совершенно нетерпимо, потому что всё здесь ложно, неправильно в своем корне, в основании» [Немецкие колонии, 1915. Земская мысль, 17].

Под «неправильным» понималось то, что немцы-колонисты не только сумели прикупить к уже полученному от Российского государства десятки тысяч десятин земли, но и отправить «очень проворных сельских писарей из колонистов» занять места членов земских управ, директоров земельных банков. Под «ложным» подразумевалось то, что с началом войны выходцы из Германии стали демонстрировать «свой до сего ничем не проявлявшийся русский патриотизм такими громкими, крикливыми словами, что их прямо стыдно и противно слушать, - по словам автора публикации, - а на деле этот патриотизм 
выражается в том, что богатейшие немецкие колонисты жертвуют ничтожные суммы, гроши на русские народные нужды во время войны, дают несколько поломанных детских кроватей на устройство лазаретов, и немцы, - не только, впрочем, колонисты, - просят о замене своих немецких фамилий русскими, для того чтобы затеряться в русской толпе» [Немецкие колонии, 1915. Земская мысль, 17].

Голословность, во всяком случае, с точки зрения серьезного обобщения, подобного рода рассуждений, на наш взгляд, легко подтверждается документом, относящимся к сентябрю 1915 г. Витебский губернатор направил телеграмму в Царское Село генерал-майору свиты Ресину, а значит - через него самому императору. В тексте послания речь шла о насильственном выселении находившегося на выборной должности головы Пфейфера и его сына, служившего исправником. Они вынуждены были переехать с семьей в город Орел к родственникам, где их арестовали и препроводили еще далее в Иркутск. Наряду с ними «беспричинному выселению подверглись председатель Дриссенской земской управы Тизенгольд и дриссенский земский начальник барон Рене» [Телеграмма витебского губернатора М.В. Арцимовича, 1915, с. 59]. Первый 24 года находился на военной службе, был в звании подполковника, являлся участником русско-японской войны, а его сын находился в российской действующей армии, был ранен. Барон Рене - правовед, «один из лучших земских начальников». По словам губернатора, который полностью мог поручиться за них, все они были выселены из района военных действий распоряжением командующего пятой армией, основанном на приказании штаба фронта [Немецкие колонии, 1915. Земская мысль, 17].

Еще один вывод, содержавшийся в газете «Земская мысль», сводился к тому, что «нужны какие-то определённые, решительные шаги, иначе могут быть очень тяжёлые столкновения между русскими крестьянами и немецкими колонистами, поскольку как это возможно, чтобы чужие всем пользовались, всё имели, всё у нас отняли, а свои были в это время у них только батраками!» [Немецкие колонии, 1915. Земская мысль, 18].

Таким образом, автор публикации определял мотивы борьбы с немецким засильем, нисколько не сомневаясь в ее необходимости и справедливости. По сути, речь шла о своеобразной военной мобилизации не только в экономической, но и в этнической сферах. Наряду и вместе с новым понятием «беженства», возникшим в начале войны, появилось новое явление общественной жизни «подданный вражеского государства», причем зачастую в обыденной жизни термин становился ярлыком и для той части этнических немцев, которые, как указывалось, многие десятилетия являлись российскими подданными.

«Результатом общественно-государственной кампании стали: вынужденное переселение приблизительно 1 млн гражданских лиц, национализация весьма значительной части имперской экономики, а также переход обширных земельных владений и городской недвижимости из рук вражеских подданных к другим влиятельным группам населения» [Лор, 2012, с. 9].

Возвращаясь к вопросу о ложном патриотизме выходцев из немецких и австрийских земель, можно привести еще один пример. К орловскому губернатору в начале августа 1914 г. обратился уроженец Тернополя в Галиции, австрийский подданный Я.М. Май, который 22 года прожил в городе Карачеве (тогда Орловской губернии, а ныне Брянской области). В своем обращении он отмечал: «Как только по мобилизации около сорока человек рабочих моей фабрики в Карачеве были призваны на действительную службу, я, будучи в душе русским человеком, дал себе слово принять все зависящие от меня меры и в пределах моих средств обеспечить как семьи призванных рабочих, так и самих рабочих, остающихся на фабрике» [О пожертвовании австрийским подданным..., 1914]. С этой целью Я.М. Май при фабрике организовал для семей нижних чинов особую, посильную работу, которая обеспечила их дополнительным заработком. Самим призванным на войну было выдано денежное пособие, а всем остальным рабочим фабрики, а их было 700 чело- 
век, было объявлено, что, невзирая на приостановку торговли из-за развернувшихся военных действий, работы на фабрике будут продолжаться, как и прежде.

К письму в адрес губернатора был приложен чек на тысячу рублей «в помощь больным и раненым воинам», а также заявлялось, что автор подал ходатайство «о принятии его в русское подданство» и готов «в будущем приносить посильную помощь и тем способствовать патриотическому делу борьбы с врагом, напавшим на давший мне приют и благосостояние русский народ» [О пожертвовании австрийским подданным..., 1914]. Трудно определить по тексту этого письма степень искренности австрийского подданного, обращавшегося в губернаторскую канцелярию. Скорее всего, поводом к этим действиям послужила развернувшаяся кампания против «немецкого засилья», страх потери нажитого в России за более чем 20 -летний период имущества, хотя не исключается вариант с искренним желанием помочь стране, с которой был связан значительный период жизни этого человека. В любом случае приведенные примеры свидетельствуют о неоднозначности применяемых мер, связанных с развернувшейся борьбой против немецких и австрийских подданных.

Проблемы колонистов были тесно связаны с сельской местностью, но периодические издания не забывали и о светской публике, рассуждали о «скверном вкусе» немцев: «...в Берлине, например, в мясных лавках выставлен ростбиф, перевязанный голубыми бантами, а среди блюда из свиных котлет красуется портрет Кайзера с лихо закрученными усами» [Блохин, 2016, с. 42]. В газетах и журналах того времени можно встретить рассуждения о низкопробности немецкого юмора, о недостатках немецкого языка и его носителей - многочисленных воспитателей-немцев, трудившихся в образовательных учреждениях и в российских семьях.

Частыми были рассуждения о косности немецкой культуры, обвинения ее в «окаменелом консерватизме», в неизменности раз и навсегда установившихся норм. Немцы обвинялись в том, что у них «одинаковые дома», «прямые улицы», не были обойдены даже особенности внешности [Немецкие колонии, 1915. Земская мысль, 18]. Доставалось и немецкой литературе: «Помню, в детстве мы плакали, когда нам дарили на елку немецкие книги. Не сказки, которые сложились за много веков до гегемонии Пруссии, а серьезные, поучительные рассказы из детской жизни. Господи! Что это была за тоска, и как мы жалели тех несчастных детей (из книги) за то, что у них были немецкие родители!» [Блохин, 2016, с. 42].

Рассуждения автора «Земской мысли» относятся к 20-м числам января 1915 г., в начале же февраля 1915 г. Особая комиссия при варшавском генерал-губернаторе высказалась «за немедленное выселение из пределов Царства Польского всех германских подданных, а также немцев-колонистов, допустив лишь возможность в случае возбуждения об этом ходатайства оставления в местах жительства всех поляков, хотя бы они считались или значились германскими и австрийскими подданными» [Выселение немцев..., 1915. Земская мысль, 33].

Причем первые выселения немцев-колонистов из приграничных районов начались гораздо раньше, в сентябре 1914 г. Главными инициаторами этих мер выступали российские военные, которые чаще всего совершенно безосновательно подозревали выходцев из Германии, уже много лет проживавших на территории России, в особых симпатиях к противнику. Отсутствие конкретных доказательств шпионской деятельности не являлось в данном случае основанием для оставления немцев-колонистов на прежних местах проживания. Инициатива отдельных корпусных командиров нашла поддержку у верховного главнокомандования.

В результате поток выселяемых немцев пополнил ряды первых переселенцевбеженцев из районов, оказавшихся под военной угрозой, преумножив проблемы российских городов, оказавшихся на пути этого движения. 
Например, издание «Новые дни», выходившее в 1915-1916 гг. в Петрограде, в начале июня 1915 г. подготовило статью, посвященную анализу некоторых из проблем, связанных с выселением «немецких и австрийских подданных» вглубь России. Представленный военному цензору материал газеты был безжалостно перечеркнут красными чернилами, но сохранился в Российском историческом архиве. «Уездный город Кологрив Костромской губернии превратился теперь в немецкий штадт (город, населенный пункт. Авт.). Германских и австрийских подданных, высланных с начала войны из прибалтийского края, насчитывается в Кологриве почти не менее постоянных городских жителей. На улицах раздаётся немецкая речь, всюду встречаются типичные немецкие физиономии, вообще «немецкое засилье» бросается в глаза каждому свежему человеку. Но особенно чувствительно «немецкое нашествие» для горожан. Квартиры вздорожали до баснословных цен: помещение, которое раньше давалось в аренду по 15 рублей, теперь даёт 40-45 рублей в месяц дохода. Высланные немцы - народ очень богатый (разбогатели на русские деньги и на русских хлебах) и нанимают лучшие в городе квартиры, не интересуясь ценой. Русское же чиновничество и учителя местных учебных заведений принуждены бесплодно искать хотя бы какие-нибудь квартиры, вымаливая у домовладельца «сделать скидку» с «немецкой таксы». Продукты первой необходимости вздорожали очень заметно, например, яйца раньше продавались 10 коп. десяток, теперь продаются 20-25 коп., а в конце марта цена доходила до 50 коп. за десяток. Масло раньше первый сорт стоило 12 коп., теперь продаётся по 18-20 коп. за фунт. Масло скорожное стоит 50-55 коп. за фунт, сахар - 22 коп. за фунт. Вообще все продукты продовольствия поднялись в цене почти вдвое. Главная причина дороговизны заключается в немцах: во-первых, нужно прокормить несколько сот лишних ртов, присланных в Кологрив в августе прошлого года; вовторых, немцы, не торгуясь при покупке съестных припасов, дали повод торговцам к недобросовестной спекуляции в смысле повышения цен. Торговцы рассуждают: «или русскому дорого, не бери, немцы возьмут с благодарностью» и стараются брать в три раза против нормальной стоимости продукта. Несмотря на обязательные постановления, немцы очень часто нарушают их. Замеченные подвергаются административным взысканиям: аресту или штрафу. В последующих корреспонденциях остановимся подробнее на жизни военнопленных и военнообязанных в северо-восточной полосе России» [Дальний, 1915. Новые дни, 46].

Волна антинемецких настроений повсеместно сопровождалась обвинениями властей в покровительстве подданным Германии, требованиями интернирования немцев. С особой силой это проявилось после первых поражений на фронте. В свою очередь, в среде выселенцев росла озлобленность: «Не скрывают своего нерасположения. Сами ничего не хотят делать. Все для них должно быть готово. Говорят все одно: "Царь нас выгнал с нашей земли, царь пусть и кормит". Бранят царя на чем свет стоит» [Кудринский, 1997, с. 89].

С немецким засильем в общественном мнении увязывался шпионаж и другие тайные формы поддержки врага. Периодическая печать зачастую открыто поддерживала эти настроения. Примером такого рода публикации может служить статья в газете «Голос Руси»: «Разумеется, одна немецкая фамилия, хотя бы и с баронским титулом в придачу, еще ничего не доказывает, - благосклонно соглашался автор статьи в газете в сентябре 1914 г. - Мало ли у нас было лиц с немецкой фамилией, преодолевших свою тевтонскую природу и принявших в себя славянскую душу!.. Однако то, что происходит в Прибалтийском крае, откуда черпаются разные наши деятели с немецкими фамилиями, доказывает с несомненностью, что край до сих пор населён истыми немцами, хотя по паспорту они и значатся русскими подданными. В самом деле, разве немецкие цеппелины не строились на деньги лифляндских баронесов? Разве мало там немцев, у которых сыновья сражаются в рядах наших врагов?» [Невероятно, но факт, 1914. Голос Руси, 243]. Последние два предложения были вычеркнуты цензором и не пропущены в печать, но это в целом не изменило общего настроя статьи [Военная цензура..., 1914]. 
Петроградская военно-цензурная комиссия вынуждена была предпринять меры для пресечения подобной «разоблачительной» активности периодических изданий. Так, на заседании военных цензоров 21 октября 1914 г. обсуждался вопрос о том, как следует относиться к статьям, касавшимся так называемого «немецкого засилья». Председатель Комиссии генерал-майор Д.П. Струков предложил следующее: «Разоблачения отдельных случаев изменнических деяний, учиненных немцами, русскими подданными допускать к печати, обобщений же, заключающих в себе огульные обвинения в измене всего немецкого населения России, не дозволять» [Журналы заседаний..., 1914].

Так, в июле 1915 г. была рассмотрена статья в газете «Свобода и порядок», которая содержала письмо унтер-офицера, негодовавшего на то, что нижний чин - колонист сдался в плен немцам, чтобы сражаться против наших войск. По поводу этой публикации было принято решение: «Статей и писем изложенного содержания к печати не дозволять» [Журналы заседаний.., 1914]. Однако в целом всё зависело от подачи материала, содержащего такого рода разоблачения, и печать продолжала осуществлять обобщения на основе частных случаев.

В большей степени с определенного момента стали применяться ограничения, связанные с конкретными лицами, носившими немецкие фамилии. Специальным приказом Верховного главнокомандующего от 25 мая 1915 г. было запрещено осуществлять нападки на тех из них, которые состояли на государственной службе. Однако год спустя, 1 мая 1916 г., цензоры на своем заседании вынуждены были признать, что в периодической печати продолжаются нападки на таких лиц [Военная цензура..., 1914]. Потенциально опасным раздувание антинемецкой истерии было из-за немалого количества немецких фамилий в российском правительстве. Более того, рано или поздно немецкое происхождение могли припомнить императрице Александре Федоровне.

Действительно, отрицательное отношение к императрице-немке стало проявляться уже в 1915 г. Например, начальник Московско-киевского жандармского полицейского управления железных дорог в декабре 1915 г. сообщал, что среди воинских чинов «высказываются резкие суждения о безответственных правителях из немцев, окружающих государя императора» [Донесение начальнику..., 1915]. Слухи о том, что царица-немка по секретному телефону сообщала противнику сведения о расположении российских войск, носили широкий характер и заметно влияли на массовое сознание. Образ внутреннего врага, формируемый с первых дней войны, постепенно стал обретать реальные черты, становившиеся все более рельефными в условиях нарастания общественного кризиса.

Лидер Конституционно-демократической партии России П.Н. Милюков в своей знаменитой речи, произнесенной 1 ноября 1916 г. в Государственной думе, буквально напрямую обвинил Б.В. Штюрмера, который являлся председателем Совета министров и министром иностранных дел, в измене. Более того, он во всеуслышание заявил, что за главой правительства стоит царица.

Императрицу обвиняли в активной деятельности в пользу врага, ей предписывалось даже распространение подпольных антивоенных листовок в столице. «Продовольственные затруднения, нараставшие в годы войны во многих городах России, "объяснялись" тем, что царица-де их вызвала намеренно, санкционируя и даже активно поощряя чрезмерный экспорт продовольственных товаров, столь необходимых для внутреннего потребления» [Колоницкий, 2010, с. 299-300].

\section{Заключение}

Дискриминационные ограничения, которые вводились относительно как немцев, так и представителей других национальностей, подданных вражеских на момент ведения войны Российской империей государств, в определенном смысле можно оправдать проблемой обеспечения государственной национальной безопасности. Однако подобные мероприятия правительства, которые стали реализовываться в отношении групп населения (в том числе и 
немецкого), подданных Российской империи, которые десятилетия назад были инкорпорированы в экономическом, социальном и культурном аспектах в российском сообществе, губительно сказались на хозяйственном укладе всей страны, перед которой стояла проблема максимальной мобилизации ресурсов для борьбы с врагом. Немалый вклад в развязывание антинемецкой кампании внесли периодические издания, на страницах которых зачастую различные группы влияний под видом борьбы с «вражеским влиянием» отстаивали свои политические или экономические интересы. Несомненно, этот фактор сыграл свою роль в развитии внутриполитического кризиса, который обозначился к середине 1915 г. и привел к серьезным социально-политическим трансформациям режима в 1917 г.

\section{Список источников}

1. Военная цензура при Петроградском комитете по делам печати Главного управления по делам печати МВД. Российский государственный исторический архив (РГИА). Ф. 778. Оп. 2. Д. 1: 3; 713: 2.

2. Выселение немцев из Царства Польского. 1915. Земская мысль, 33: 7 февраля.

3. Донесение начальнику Орловского жандармского управления. Государственный архив Орловской области (ГАОО). Ф. 883. Оп. 1. Д. 790: 348.

4. Журналы заседаний военных цензоров и членов Петроградского комитета по делам печати. РГИА. Ф. 778. Оп. 1. Д. 6: 12, 30 об.

5. Манифест. О дозволении всем иностранцам, в Россию въезжающих, поселятся в которых губерниях они пожелают и её дарованных им правах. 1763. Полное собрание законов Российской империи. Собр. 1. Т. 16: 11. 880.

6. Меры борьбы с германским засильем (анкета Московского купеческого общества). 1915. РГИА. Ф. 778. Оп. 2. Д. 238: 13.

7. Невероятно, но факт. 1914. Голос Руси, 243: 6 сентября.

8. Немецкие колонии. 1915. Земская мысль, 17-18: 21-22 января.

9. О пожертвовании австрийским подданным Я.М. Май 1000 руб. на военные нужды. 1914. ГАОО. Ф. 580. Ст. 3. Д. 7500: 1-1 об.

10. Телеграмма витебского губернатора М.В. Арцимовича генерал-майору свиты его величества А.А. Ресину о характеристике депортированных из Витебской губернии служащих немецкого происхождения. 1915. Сентябрь. Беларусь в годы Первой мировой войны (1914-1918): Сборник документов. Сост. В.В. Врублевский и др. Минск, Беларусь, 2014. 355.

\section{Список литературы}

1. Блохин В.Ф. 2016. «Героическое» на страницах иллюстрированного журнала «Лукоморье» 1914-1917 гг. Россия в эпоху политических и культурных трансформаций. Брянск: $37-60$.

2. Дальний В. 1915. Письма из провинции. Новые дни, 46: 3 июня.

3. Ерохина О.В. 2014. «Ликвидационное законодательство» Первой мировой войны. Вестник Московского государственного гуманитарного университета им. М.А. Шолохова. История и политология, 1: 69-81.

4. Колоницкий Б.И. 2010. Трагическая эротика. Образы императорской семьи в годы Первой мировой войны. Москва, Новое литературное обозрение, 664.

5. Кудринский Ф.А. Людские волны. Беженцы. 1997. Неман, 6: 79-193.

6. Лор Э. 2012. Русский национализм и Российская империя: Кампания против «вражеских подданных» в годы Первой мировой войны. Перевод с английского В. Макарова. Москва, Новое литературное обозрение, 304.

7. Фуллер У. 2009. Внутренний враг. Шпиономания и закат императорской России. Авторизованный пер. с английского М. Маликовой. Москва, Новое литературное обозрение, 376. 


\section{References}

1. Blokhin V.F. 2016. «Geroicheskoe» na stranitsakh illyustrirovannogo zhurnala «Lukomor'e» 1914-1917 gg. Rossiya v epokhu politicheskikh i kul'turnykh transformatsiy [«Heroic» on the Pages of the Illustrated Magazine «Lukomorye» 1914-1917. Russia in the Era of Political and Cultural Transformations]. Bryansk: 37-60 (in Russian). Russian).

2. Dal'niy V. 1915. Pis'ma iz provintsii [Letters from the Province]. Novye dni, 46: 3 iyunya (in

3. Erokhina O.V. 2014. «Likvidatsionnoe zakonodatel'stvo» Pervoy mirovoy voyny [«Liquidation Legislation» of the First World War]. Vestnik Moskovskogo gosudarstvennogo gumanitarnogo universiteta im. M.A. Sholokhova. Istoriya i politologiya, 1: 69-81 (in Russian).

4. Kolonitskiy B.I. 2010. Tragicheskaya erotika. Obrazy imperatorskoy sem'i v gody Pervoy mirovoy voyny [Tragic Erotica. Images of the Imperial Family during the First World War]. Moscow, Novoe literaturnoe obozrenie, 664 (in Russian).

5. Kudrinskiy F.A. Lyudskie volny. Bezhentsy [Human waves. Refugees]. 1997. Neman, 6: 79-193.

6. Lor E. 2012. Russkiy natsionalizm i Rossiyskaya imperiya: Kampaniya protiv «vrazheskikh poddannykh» v gody Pervoy mirovoy voyny [Russian Nationalism and the Russian Empire: Campaign against «Enemy Subjects» during the First World War]. Perevod s angliyskogo V. Makarova. Moscow, Novoe literaturnoe obozrenie, 304 (in Russian).

7. Fuller U. 2009. Vnutrenniy vrag. Shpionomaniya i zakat imperatorskoy Rossii [The Internal Enemy. Spy Mania and the Decline of Imperial Russia]. Avtorizovannyy per. s angliyskogo M. Malikovoy. Moscow, Novoe literaturnoe obozrenie, 376 (in Russian).

\section{ИНФОРМАЦИЯ ОБ АВТОРЕ}

Николаева Елена Владимировна, аспирант кафедры отечественной истории, начальник отдела международных связей и сотрудничества Брянского государственного университета им. академика И.Г. Петровского, г. Брянск, Россия

\section{INFORMATION ABOUT THE AUTHOR}

Elena V. Nikolaeva, Post-Graduate Student, National History Department, Head of International Relations and Cooperation Department, Bryansk State University named after academician I.G. Petrovsky, Bryansk, Russia 